Santa Clara University

Scholar Commons

Accounting

Leavey School of Business

$7-2008$

\title{
Ethics and disclosure: a study of the financial performance of firms in the seasoned equity offerings market
}

Hoje Jo

Yongtae Kim

Santa Clara University, y1kim@scu.edu

Follow this and additional works at: http://scholarcommons.scu.edu/accounting

Part of the Accounting Commons

\section{Recommended Citation}

Jo, Hoje, and Yongtae Kim. "Ethics and Disclosure: A Study of the Financial Performance of Firms in the Seasoned Equity Offerings Market." Journal of Business Ethics 80.4 (2008): 855-78.

The final publication is available at Springer via http://dx.doi.org/10.1007/s10551-007-9473-6.

This Article is brought to you for free and open access by the Leavey School of Business at Scholar Commons. It has been accepted for inclusion in Accounting by an authorized administrator of Scholar Commons. For more information, please contact rscroggin@scu.edu. 


\title{
ETHICS AND DISCLOSURE: A Study of the Financial Performance of Firms in the Seasoned Equity Offerings Market
}

\author{
Hoje Jo and Yongtae Kim
}

April 2007

Jo is from the Department of Finance, Leavey School of Business, Santa Clara University, Santa Clara, CA 95053-0388, Tel.: 408-554-4779, Fax: 408-554-4029, E-mail: hjo@scu.edu. Kim is from the Department of Accounting, Leavey School of Business, Santa Clara University, (408) 554-4667, (408)-554-5193 (Fax), Email: y1kim@scu.edu. The authors are grateful to Section Editor, Sally Gunz, two anonymous referees, Shawn Berman, David DeCosse, Kitty Murphy, Alex Zecevic, and other Ignatian Faculty Forum (IFF) participants of Santa Clara University for their many valuable comments. Jo acknowledges support from the Hackworth Grant and the Markkula Center for Applied Ethics. Kim acknowledges support from the Accounting Development Fund at Santa Clara University. 


\title{
Ethics and Disclosure: A Study of the Financial Performance of Firms in the Seasoned Equity Offerings Market
}

\begin{abstract}
In this article, we examine the association between ethics and disclosure and the impact of this association on the long-term, post-issue performance of seasoned equity offerings (SEOs). We argue that firms with extensive disclosure are less likely to face information problems, and more likely to lead to active shareholder monitoring, and therefore, engage in fewer unethical activities, such as aggressive earnings manipulation, and have better long-term, post-issue performance. Consistent with these predictions, this study presents evidence that disclosure is negatively related to unethical earnings manipulation and positively associated with long-term, post-issue performance. In particular, we find that long-term, post-issue SEO underperformance is significantly less for firms with extensive disclosure and conservative earnings management than firms with less disclosure and aggressive earnings management. We interpret this evidence to mean that over the long run, the capital market values ethical financial reporting and corporate efforts to incorporate social responsibility into their decision-making processes, for example, by enhancing information transparency through voluntary disclosure.
\end{abstract}

JEL classification: G14; G24; G32; M14; M41

Key Words: Ethics, Social responsibility, Disclosure, Earnings management, Seasoned equity offerings, Long-term, post-issue performance 
One of the most significant corporate trends of the last decade is the growth of Corporate Social Responsibility (CSR). ${ }^{1}$ More than half of the Fortune 1,000 companies regularly issue CSR reports and a large number of firms are engaged in a serious effort to define and integrate CSR into various aspects of their business. Definition of CSR varies, however. Friedman (1970) first defines CSR as follows: "Corporate social responsibility is to conduct the business in accordance with shareholders' desires, which generally will be to make as much money as possible while conforming to the basic rules of society, both those embodied in law and those embodied in ethical custom." McWilliams and Siegel (2001) define CSR as actions that appear to further some social good, beyond the firm's interests and that which is required by law. Hill et al (2007) define CSR as the economic, legal, moral, and philanthropic actions of firms that influence the quality of life of relevant stakeholders. Barnea and Rubin (2005) suggest that while definitions of CSR vary, it generally refers to serving people, communities and environment in a way that goes beyond and above what is legally required of a firm.

While CSR is closely related to ethical issues concerning corporate decision-making and behavior, recent accounting scandals by such renowned companies as AOL Time Warner, Enron, Merck, Qwest Communications, WorldCom, Xerox, Parmalat (the European version of Enron), Daewoo, and SK Global (Korean conglomerates) have raised serious concerns among market participants about ethical issues in a global world. These companies have disregarded ethics and placed more emphasis on short-term gains to top management by manipulating their earnings. ${ }^{2}$

\footnotetext{
${ }^{1}$ See, for example, Tsoutsoura (2004). She suggest that an increasing number of shareholders, analysts, regulators, activists, labor union, employees, community organizations, and news media are asking companies to be accountable for an ever-changing set of CSR issues.

${ }^{2}$ Corporate social responsibility and business ethics are often regarded as the same concepts. However, the CSR movement is one aspect of the overall discipline of business ethics. The CSR movement arose particularly during the 1960s with increased public consciousness about the role of business in helping to cultivate and maintain highly ethical practices in society and particularly in the natural environment.
} 
In this paper, we define unethical firms as firms that manipulate their earnings aggressively. ${ }^{3}$ Similarly, we define ethical firms as firms choosing ethical reporting, i.e., conservative earnings management. In addition, we define more frequent and persistent disclosures that make the firm's information environment transparent as socially responsible (or transparency-increasing) disclosures, similar to the argument made by Gelb and Strawer (2001). We also define less frequent and non-persistent disclosures that make information environment opaque as socially irresponsible (or transparency-decreasing) disclosures. Based on these definitions, we first examine the endogenous relation between ethical behavior in financial reporting and disclosure. We then examine whether the firms with ethical financial reporting and socially responsible disclosures perform better financially than unethical firms with less disclosure in terms of their long-term, post-issue performance in the U.S. seasoned equity offerings (SEOs) market.

We choose the SEO market because of the well-known evidence indicating that firms issuing equity inflate their stock price temporarily via earnings manipulation around SEOs and that market participants fail to adjust for earnings manipulation adequately, leading to postoffering stock underperformance (Teoh, Welch, and Wong, 1998; DuCharme, Malatesta, and Sefcik, 2004). Casual observation suggests that there is a wide variation in disclosure strategies. Some firms communicate continuously with investors through voluntary disclosure, while others provide very little information.

\footnotetext{
${ }^{3}$ Schipper (1989) defines earnings management as "purposeful intervention in the external reporting process, with the intent of obtaining some private gain to managers or shareholders." Healey and Wahlen (1999) define earnings management as follows: Earnings management occurs when managers use judgment in financial reporting and in structuring transactions to alter financial reports to either mislead some stakeholders about the underlying economic performance of the company, or to influence contractual outcomes that depend on the reported accounting numbers. We follow these definitions of earnings management throughout the paper.
} 
Recently, Jo and Kim (2007) suggest that disclosure frequency is inversely related to earnings management and positively associated with one-year post-issue performance. However, while both disclosure and earnings management decisions are endogenously determined, they address neither the endogenous natures of disclosure and earnings management nor the long-term consequence of these decisions. We explore the possible relation among ethics, disclosure, and the long-term consequences of socially responsible disclosure and ethical reporting practices by investigating long-term financial performance.

We first hypothesize that aggressive earnings management is inversely associated with socially responsible disclosure, and vice versa. We also hypothesize that firms with aggressive earnings management and socially irresponsible disclosure tend to have inferior long-term return performance, to the extent that investors, in general, prefer stocks of ethical companies over those of unethical companies, and socially responsible firms over irresponsible firms, if other factors are held constant.

Using the number of press releases by searching press-release wires in the Dow Jones Interactive (DJI) database system as a measure of disclosure, we find evidence that the disclosure of U.S. SEO firms is endogenously and inversely associated with our measure of earnings manipulation: performance-adjusted discretionary total accruals (ADTA), as suggested by Kothari, Leone, and Wasley (2005). Additionally, the long-term, post-issue SEO performance of firms with high disclosure and conservative earnings management is significantly better than that of firms with low disclosure and aggressive earnings management over the five-year period after the offering. Based on these results, we conclude that ethical perspectives and social responsibility make a significant impact on the equity offering market over the long run. 
This paper contributes to the CSR and financial-performance literature in two ways. First, to the best of our knowledge, our paper is the first attempt to address the endogenous association between ethical reporting and socially responsible disclosure (as a part of CSR) around SEOs. This study is important in light of recent financial scandals suggesting that many highly reputed U.S. firms disregard ethics and manipulate their earnings. Second, this paper addresses the relation between the combined effect of ethical reporting and socially responsible disclosure and its impact on long-term, post-offering SEO performance, and therefore it sheds additional light on the issue of whether the equity offering market, in general, values social responsibility through voluntary disclosure and ethical aspects by earnings management over the long term.

\section{Corporate Social Responsibility and Financial Performance}

The relation between social responsibility activities and financial performance has been an important topic of debate at least since 1960. Oberman (2000) refers to academic debates over CSR even taking place in the 1920s. These debates are still developing and represent some of the important potential role of CSR and its impact on valuation both dynamic and vital. The literature we briefly review consists of three principal strands: 1) model predictions of CSR; 2) empirical relation between CSR and financial performance; and 3) link between socially responsible investing and CSR.

\section{Model predictions of CSR}

We first briefly review theory and model predictions of the relation between CSR and financial performance. The theoretical model predictions of CSR vary. Some CSR models 
predict that CSR expenditures will increase stock price up to certain point. Navarro (1988) assumes that CSR spending improves the quantity of sales, while Webb (1996) assumes that CSR spending improves price. Other model predicts that CSR expenditure will not affect stock price. In the simple world where there are no frictions, Small and Zivin (2002) develop a Modigliani-Miller's (1958) irrelevance result by showing that if the investor optimally wishes to donate, the two firms' stock prices will be equal and they will be independent of the level of donation made. Van De Ven and Jurissen (2005) maintain that although the mainstream of current thinking in business ethics recognizes that a firm should invest in CSR, the normative theory of how specific, competitive conditions affect a firm's social responsibility remains underdeveloped.

\section{Empirical studies of CSR}

According to Margolis and Walsh (2003), over one hundred and twenty studies between 1971 and 2001 have examined the empirical relation between CSR and financial performance, and the results are largely inconclusive. Wood and Jones (1995) and Margolis and Walsh (2003) suggest that assessments of previous studies are complicated because of the imperfect nature of many studies, such as measurement problems of both CSR and financial performance, omitted variable problems, lack of the necessary analysis of causality and/or endogeneity, lack of methodological rigor in many studies, and lack of theory. Nonetheless these studies stress that bad social performance is detrimental to a firm's financial performance.

While it is abstruse to draw a definite conclusion due to the imperfect nature of many studies, most recent reviews of the empirical CSR literature conducted by Margolis and Walsh 
(2003) and Orlitzky et al (2003) indicate a positive relation between investing in socially responsible activities and financial performance.

\section{Link between socially responsible investing and CSR}

The link between SRI and CSR has also received considerable research attention recently, particularly in terms of financial performance. ${ }^{4}$ The value of SRI in financial markets is also, at best, mixed and inconclusive. While some findings indicate that ethical aspects do not affect the financial performance of SRI (Hamilton, Jo, and Statman, 1993; Statman, 2000; Kreander, Gray, Power, and Sinclair, 2005), other studies suggest that creating and implementing ethical codes of conduct have significant implications for financial communities (Hellsten and Mallin, 2006). Barnet and Salomon (2006) suggest that various screening criteria of SRI result in different impacts on financial performance and show that while community-relations screening increases financial performance, environmental and labor relations screening decreases financial performance.

\section{Hypothesis: Ethics and Disclosure}

While the most researchers focus on the relation between CSR and financial performance, some researchers have devoted considerable attention to firms' policies regarding voluntary disclosure. For instance, previous studies (e.g, Botosan, 1997; Lang and Lundholm, 2000) suggest that equity-issuing firms can increase their stock prices by reducing their cost of

\footnotetext{
${ }^{4}$ There is an increasing trend toward a conscious awareness of ethical issues in the investment community. According to the Social Investment Forum's fifth biennial report on socially responsible investment (SRI) trends (2006), SRI assets grew faster than the entire universe of managed assets in the United States over the last 10 years. Total socially responsible investment assets rose more than 258 percent from $\$ 639$ billion in 1995 to $\$ 2.29$ trillion in 2005 , while the broader universe of assets under professional management increased less than 249 percent from $\$ 7$ trillion to $\$ 24.4$ trillion over the same period.
} 
capital through voluntary disclosure. On the other hand, Gelb and Strawer (2001) argue that firms disclose because it is socially responsible to do so. They maintain that companies have incentives to engage in stakeholder management by undertaking socially responsible activities and that providing extensive and informative disclosures is one such practice. Based on disclosure rankings provided by the annual Association for Investment Management and Research (AIMR) Reports, they suggest that there is a positive relation between disclosure level and CSR and conclude that increased disclosure is a form of socially responsible behavior. Following Gelb and Strawer (2001), we use a persistent and frequent disclosure over an extended period as socially responsible, transparency-increasing disclosure.

\section{The endogenous nature of ethics and disclosure}

One possible linkage between ethical reporting and socially responsible disclosure is through information transparency. To examine the relation between ethical reporting and disclosure, we first consider their endogenous nature. In general, we expect that better information environment through extensive disclosure enhance investor's awareness of ethical aspects. For instance, Schipper (1989) argues that the absence of full communication (or the existence of blocked communication) together with asymmetric information makes it possible for managers to engage in unethical behaviors, such as earnings manipulation. Consequently, we expect that corporate incentives for unethical decision making, such as earnings manipulation, will be high when information asymmetry regarding the firm's economic earnings is high. Conversely, with less information asymmetry through persistent and frequent disclosures, managers will be less likely to manipulate earnings. While the previous discussion suggests that extensive disclosure reduces the incentive for earnings management, it is also possible that lower disclosure is induced by a desire to manipulate earnings. Hence, we have: 
Information Hypothesis: Unethical corporate behavior, such as aggressive earnings manipulation, is inversely associated with voluntary disclosure, while corporate-responsibility-enhancing decisions, such as transparency-increasing disclosure, are endogenously determined as a negative function of earnings management.

\section{Long-term, post-issue SEO performance}

The relation between social responsibility activities and financial performance has been an important topic of debate at least since 1960. Oberman (2000) refers to academic debates over CSR even taking place in the 1920s. These debates are still developing and represent some of the important potential role of CSR and its impact on valuation both dynamic and vital.

The literature of agency problems and corporate disclosure can provide an important insight into the relation between socially responsible disclosure and long-term financial performance. In their seminal work on agency problems, Jensen and Meckling (1976) suggest that outside shareholder monitoring helps reduce the agency costs associated with the separation of ownership and control. In a related vein, Merton (1987) states that:

"...For example, a newspaper or other mass media story about the firm or its industry that reaches a large number of investors who are not currently shareholders, could induce some of this number to incur the set-up costs and follow the firm. Having done so, in our model, these investors would evaluate the detailed substantive information about the firm, become new shareholders, and value of the firm would rise. It should be stressed that the current shareholders may already know all the information contained in such stories. Nevertheless, if the form of the prior public releases of the information did not capture widespread attention among investors who do not follow the stock and if the new form does, the firm's investor base will increase and the stock price will rise." (pp. 500-501).

From Merton (1987), we can infer that persistent and frequent disclosures can enhance investor cognizance or attention, thus enlarging the shareholder pool and increasing shareholder monitoring. We argue that this increased monitoring, along with the reduction of information 
asymmetry reduces the long-term, post-issue SEO underperformance. ${ }^{5}$ In addition, the monitoring role of disclosure has both concurrent and lasting effects on a SEO's post-issue performance. Because investors become new shareholders at various times, the pool of shareholders increases not only during the pre-offering period but also during the post-issue period. As a result, outside shareholder monitoring has an almost continuous and lasting impact on post-issue performance. ${ }^{6}$ Furthermore, maintaining a high level of disclosure over an extended period (even after the offering date) is important to holding investor attention. ${ }^{7}$

Prior research shows that firms engaging in unethical reporting, such as incomeincreasing earnings management around SEOs, suffer with lower stock price in the long-run. In particular, Teoh, Welch, and Wong (1998a, b) and Rangan (1998) find that long-run, post-issue performance is negatively related to earnings management. This relation between unethical reporting and long-run underperformance will be stronger when the effect of unethical reporting is combined with that of socially irresponsible disclosure.

In short, disclosure plays an important role in reducing post-issue SEO underperformance because corporate self-monitoring and outside market monitoring help reduce agency costs

\footnotetext{
${ }^{5}$ In a similar line of reasoning, Chung and Jo (1996) claim that security analysts' monitoring of firm performance helps motivate managers, thus reducing the agency costs associated with the separation of ownership and control. They find that analyst following exerts a significant positive impact on a firm's market value. Recently, Hartzell and Starks (2003) suggest that institutional investors also serve a monitoring role in mitigating the agency problem between shareholders and managers.

${ }^{6}$ There are direct and indirect effects of disclosure on post-issue performance. To see these points more clearly, note first that the relation among post-issue performance (P), disclosure (DL), and earnings management (EM) can be depicted by the functional form $\mathrm{P}=\mathrm{f}\{\mathrm{DL}, \mathrm{EM}(\mathrm{DL})\}$. Notice that disclosure has both a direct and an indirect effect (through its impact on earnings management) on post-issue performance. Next, note that the total derivative of $\mathrm{P}$ with respect to $\mathrm{DL}$ is $\mathrm{dP} / \mathrm{dDL}=\partial \mathrm{P} / \partial \mathrm{DL}+(\partial \mathrm{P} / \partial \mathrm{EM})(\mathrm{dEM} / \mathrm{dDL})$, where $\partial \mathrm{P} / \partial \mathrm{DL}$ is the direct effect of disclosure on post-issue performance and $(\partial \mathrm{P} / \partial \mathrm{EM})(\mathrm{dEM} / \mathrm{dDL})$ is the indirect effect of disclosure through earnings management on post-issue performance. According to our monitoring argument, we expect to have $\partial \mathrm{P} / \partial \mathrm{DL}>0$. In accordance with our information hypothesis, we expect to have dEM/dDL $<0$ and according to Teoh, Welch, and Wong (1998a) and Rangan (1998), we expect $\partial \mathrm{P} / \partial \mathrm{EM}<0$. As a result, the total (net) effect (i.e., dP/dDL) of disclosure on post-issue performance is positive.

${ }^{7}$ Regarding earnings management, Rangan (1998) and Jo and Kim (2007) suggest that firms manage earnings even after the offering due to their concerns over lawsuits and lock-up agreements with underwriters.
} 
through increased investor attention. Together with previously reported evidence of long-run, post-issue underperformance of unethical firms, this implication lead us to the following hypothesis.

Monitoring Hypothesis: (a) Socially responsible disclosure: Long-term, post-issue SEO performance is an increasing function of socially responsible, transparency-increasing disclosure because of its monitoring role that reduces agency problems; (b) Disclosure and ethical reporting: Long-term, post-issue SEO underperformance is largest for SEO firms that engage in unethical financial reporting and socially irresponsible disclosure.

\section{Data and Research Design}

\section{Data description}

We obtain an initial sample of all U.S. common stock SEOs that occur between January 1990 and December 1997 from the Securities Data Corporation (SDC) database. We also examine post-offering returns up to five years after the offerings (i.e., up to 2002). We search for press releases (our proxy of disclosure activity) for our sample firms from the press-release wires in the Dow Jones Interactive (DJI) database system. We limit the sample to firms that are available on the COMPUSTAT and CRSP (Center for Research in Stock Price) databases. Offerings by financial institutions are excluded because the nature of these firms' accruals differs from that of industrial firms. Our final sample consists of 1,431 offerings. We obtain the ownership data (institutional ownership, block ownership, and insider ownership) from the Spectrum of Compact Disclosure. Actual samples used in the analyses are different, since the data availability varies for each regression analysis. We use the latest data available prior to the offering announcement.

SEO announcement dates are obtained from the DJI database. We search for SEO announcements (including intention to file, approval by the company's board, and stockholders' 
approval) within the two years preceding the SEO filing date reported in the SDC database. When we cannot find the SEO announcement before the SEO filing date, we treat the SEO filing date as the SEO announcement date.

Research design

Due to the endogenous nature of ethics and disclosure, we employ a three-stage leastsquares (3SLS) regression to estimate the simultaneous model as follows.

$D L=a+b_{1} * A D T A+$ control variables,

$A D T A=a+b_{1} * D L+$ control variables,

where DL is our disclosure measure, an average percentile rank of the number of press releases per six-month period over $\mathrm{M}(-4)$ through $\mathrm{M}(+3)$, following Jo and Kim (2007) (see the calculation of DL in Appendix A); ADTA is our earnings manipulation measure, the annualized performance-adjusted discretionary total accrual scaled by lagged total assets, following Kothari et al. (2005). In particular, we estimate earnings management with performance-adjusted discretionary total accruals, as suggested by Kothari et al. (2005). They show that existing methods for estimating discretionary accruals are biased toward rejecting the null hypothesis of no earnings management when the event related to the incentive is associated with performance. Kothari et al. (2005) recommend adjusting discretionary accruals by subtracting discretionary accruals of control firms matched on prior-year ROA and industry. Following Kothari et al. (2005), we match each SEO firm with a non-SEO firm from the same industry (using the twodigit SIC code), with the closest ROA (net income divided by lagged total assets) in the year ending prior to $\mathrm{Q}(-1)$. ADTA is the discretionary accruals of the SEO firm minus the discretionary accruals of the performance matched, non-SEO firm, summed over $\mathrm{Q}(-1)$ to $\mathrm{Q}(+2)$ 
and scaled by assets at the beginning of $\mathrm{Q}(-1)$. Discretionary total accruals are estimated by the cross-sectional modified Jones (1991) model using two-digit SIC codes. Figure 1 shows our timing convention.

[Insert Figure 1 about here.]

$\mathrm{Q}($.$) represents the quarters around a SEO. The quarter of the last earnings announcement before$ the offering announcement is labeled $Q(-1) . Q(0)$ is the quarter of the first earnings announcement after the offering announcement. All other quarters are similarly indexed relative to the offering announcement. $M($.$) is the six-month period in which disclosure frequencies are$ determined. $M(-1)$ is the last six-month period prior to the SEO announcement, and $M(0)$ is the first six-month period after the SEO announcement. All other six-month periods are similarly indexed relative to the offering announcements.

\section{Control variables and the structural model}

Considering potential endogeneity, we employ a structural model for an empirical representation of the relation between disclosure (DL) and earnings management proxied by performance-adjusted discretionary total accruals (ADTA). To reduce the possibility of model misspecification due to missing variables, we control for additional variables in the model. King, Pownall, and Waymire (1990), Lang and Lundholm (1993), and Skinner (1994) find that disclosure activities are positively associated with firm size and return volatility, and negatively associated with performance, change of performance, and return-earnings correlation. Thus, we include these as explanatory variables for the disclosure regressions. Disclosure might vary with the economic and market environment, corporate governance, and the firm's ownership structure, 
as well as the availability of other sources of firm information. To capture these effects on disclosure, we use control variables, including institutional ownership, blockholder ownership, insider ownership, and the number of analysts following the firm.

Numerous studies have documented that earnings management is negatively associated with operating cash flow, change in performance, auditor quality, and the absolute value of total accruals (Dechow, 1994; Burgstahler and Dichev, 1997; Becker, DeFond, Jiambalvo, and Subramanyam, 1998). We thus include operating cash flow, change in return on assets (ROA), auditor quality, and the absolute value of total accruals as explanatory variables. In addition, we include firm size, leverage, and ownership variables as additional control variables in our earnings management regressions.

Since an application of ordinary least squares (OLS) to a simultaneous equations model can yield biased and inconsistent parameter estimates, we employ a three-stage least-squares (3SLS) regression to estimate the simultaneous model as follows. (The expected signs are noted above each coefficient.)

$$
\begin{aligned}
& D L=a+\bar{b}_{1} * A D T A+\bar{b}_{2} * R O A+\overline{b_{3}} * C R O A+\bar{b}_{4} * A R \_b f 6 m \\
& +\quad-\quad+\quad+ \\
& +b_{5} * S I Z E+b_{6} * R E+b_{7} * S T D 10 Y R+b_{8} * I N S T I \\
& +\quad+\quad+ \\
& +b_{9} * B L O C K+b_{10} * I N S I D E R+b_{11} * N U M \_A N S T+e \text {, } \\
& A D T A=a+\bar{b}_{1}^{*} D L+\bar{b}_{2}^{*} \mathrm{OCF}+\bar{b}_{3}^{*} \mathrm{CROA}+{ }_{b_{4}}^{*} \operatorname{SIZE} \\
& +b_{5} * L E V+b_{6} * I N S T I+b_{7} * B L O C K+b_{8} * I N S I D E R+b_{9} * N O N B 6 \\
& +\bar{b}_{10} * A B S T A C C+e
\end{aligned}
$$


where DL is an average percentile rank of the number of press releases per six-month period over $\mathrm{M}(-4)$ through $\mathrm{M}(+3)$; ADTA is the annualized performance-adjusted discretionary total accrual over the period $\mathrm{Q}(-1)$ through $\mathrm{Q}(+2)$ scaled by lagged total assets; ROA is an annualized return on assets (ROA) measured as income before extraordinary items summed over $\mathrm{Q}(-1)$ to $\mathrm{Q}(+2)$ and scaled by assets at the beginning of $\mathrm{Q}(-1)$; CROA is the changes in annualized ROA measured as income before extraordinary items summed over $\mathrm{Q}(+3)$ to $\mathrm{Q}(+6)$ and scaled by assets at the beginning of $\mathrm{Q}(+3)$ minus income before extraordinary items summed over $\mathrm{Q}(-1)$ to $\mathrm{Q}(+2)$ and scaled by assets at the beginning of $\mathrm{Q}(-1)$; AR_bf6m is the marketadjusted returns over the one-year period ending 6 months before the offering announcement. Market-adjusted returns are computed by subtracting the return on the value-weighted market index from firm returns; SIZE is the log of the market value of equity at Q(-1); RE is an annual return/earnings correlation measured over 10-year period before the offering announcement; STD10YR is the standard deviation of market-adjusted returns over the 10 years prior to the offering announcement; INSTI is the percentage ownership of institutional investors; BLOCK is the percentage ownership of blockholders; INSIDER is the percentage ownership of insiders; NUM_ANST is the number of analysts' following the firm; OCF is the operating cash flow over the period $\mathrm{Q}(-1)$ through $\mathrm{Q}(+2)$ scaled by the lagged total assets; LEV is the debt-to-equity ratio, the proxy for the closeness to the violation of lending contracts; NONB6 is an indicator variable, which is set equal to 1 if the firm's auditor is not one of big six accounting firms, and 0 otherwise; and ABSTACC is the absolute value of total accruals over the period Q(-1) through $\mathrm{Q}(+2)$ scaled by the lagged total assets.

Measurement of long-term SEO performance 
To examine the long-term SEO performance for up to five years after a SEO, we follow the Fama \& French (1993) three-factor model approach and run the following regression for individual securities in each group classified based on disclosure and earnings management.

$\left(R_{i t}-R_{f t}\right)=\alpha+b_{1}\left(R_{m t}-R_{f t}\right)+b_{2} S M B_{t}+b_{3} H M L_{t}+e_{i t}$

where $R_{i t}$ is the monthly return of SEO firm i. $R_{m t}-R_{f t}$ is the market excess return in month $t$. $\mathrm{SMB}_{\mathrm{t}}$ is the difference between the month $\mathrm{t}$ return on a value-weighted portfolio of small stocks and one of large stocks. $\mathrm{HML}_{\mathrm{t}}$ is the difference between month $\mathrm{t}$ return on a value weighted portfolio of high book-to-market stocks and one of low book-to-market stocks, and $\mathrm{e}_{\mathrm{it}}$ is the error term.

\section{Descriptive statistics}

Table I reports the sample statistics and data characteristics for the 1,431 offerings.

[Insert Table I about here.]

Panel A of Table I shows that seasoned equity issues are not clustered by time periods, except that 1990 carries only $5.8 \%$ of the issues. Panels B and C provide summary information on issuer size and offering characteristics. The mean and median of book value of assets are $\$ 988$ million and \$146 million, respectively. The mean and median of the equity market capitalization are $\$ 780$ million and $\$ 200$ million, respectively. Issuer size varies considerably as indicated by the large standard deviation. The mean and median offering proceeds are $\$ 81$ million and $\$ 43$ million respectively. The mean increase in shares due to the offering is $26 \%$.

\section{Empirical Results}




\section{Bivariate relations}

Before we proceed to the multivariate analysis, it is informative to examine whether the bivariate relations between disclosure and earnings management are consistent with our hypotheses. The bivariate correlation coefficients are reported in Table II.

\section{[Insert Table II about here.]}

Table II presents the pearson correlation coefficients among the variables used in the regression analyses. The bivariate correlation coefficient between disclosure and earnings management variable is significantly negative. ${ }^{8}$

Figure 2 illustrates the bivariate relations among disclosure, earnings management, and post-issue performance.

[Insert Figure 2 about here.]

The figure shows the post-issue performance (i.e., market-adjusted returns compounded daily over the one-year period after the $\mathrm{Q}(+2)$ earnings announcement) for different levels of disclosure when earnings management varies. After controlling for earnings management, post-issue performance and disclosure are positively correlated, supporting our monitoring hypothesis (a). In addition, as expected, the greater the disclosure, the lower the earnings management measured by the ADTA at all levels of the post-issue performance, supporting the information hypothesis. Overall, this suggests that our bivariate results are consistent with both of our hypotheses.

\section{The simultaneous association between disclosure and earnings management}

\footnotetext{
${ }^{8}$ Our unreported results suggest that the negative relation between disclosure and the earnings management variable does not change with measurements across various time spans or other proxies of earnings management.
} 
To incorporate the endogenous characteristics of disclosure and earnings management, we present the results of the 3SLS regressions in Table III.

[Insert Table III about here.]

The 3SLS regression results show that the included variables jointly account for nearly $26 \%$ of the variation in disclosure and earnings management. As hypothesized, there is a significant and negative, bidirectional relation between disclosure and earnings management. The results show that the ADTA yields a significant, negative impact on the DL. Likewise, the DL also exerts a significant, negative influence on the ADTA. Specifically, the estimated regression coefficient suggests that a $1 \%$ increase in the ADTA results in a $0.3715-0.3718 \%$ decrease in the DL. Similarly, we find that a $1 \%$ increase in the DL results in a $0.6543-0.8296 \%$ decrease in the ADTA. The combined results provide empirical support for our information hypothesis that disclosure is a decreasing function of earnings management and earnings management is a decreasing function of disclosure. The former evidence is consistent with the single-equation OLS evidence of Jo and Kim (2007). Our unreported results suggest that the results remain qualitatively unchanged using other proxies of earnings management, such as the discretionary current accruals (DCA) that Teoh, Welch, and Wong (1998a, b), Rangan (1998), and DuCharme, Malatesta, and Sefcik (2004) use, and the discretionary total accruals (DTA) that Hribar and Collins (2002) suggest. Different measurement windows of accruals and disclosure do not change the results.

Managers of firms with unusual income-decreasing accruals have a strong incentive to provide extensive disclosure at the time of an equity offering in order to prevent possible lawsuits from investors and to make sure that investors do not misinterpret their poor reported 
performance. Skinner (1994) suggests managers have legal incentives to disclose bad news. Skinner (1997) also provides evidence on the relation between earnings disclosure and stockholder litigation. After controlling for confounding factors, he finds that voluntary disclosures occur more in quarters that result in litigation than in quarters that do not and more timely disclosure is related to lower settlement amounts.

To rule out this alternative explanation (i.e., firms with unusual income-decreasing accruals provide extensive disclosure to make sure that investors do not misinterpret their poor reported performance) of a negative relation between earnings management and disclosure, we conduct the 3SLS regression using only income-increasing accruals, i.e., positive ADTA only. The results reported in the right hand side of Table III suggest a strong and negative relation between ADTA and DL. The relation is statistically insignificant when we conduct the same tests with samples of income-decreasing discretionary accruals only. Combined together, these results provide convincing evidence that firms with extensive disclosures are less likely to manipulate earnings.

Consistent with Skinner's (1994) finding, we find that performance measured by annualized ROA and changes in performance measured by changes in annualized ROA are negatively associated with voluntary disclosure. These results support Skinner's premise that firms that are performing poorly disclose more in order to reduce expected legal costs. Our results also suggest that firm size is positively related to disclosure. This supports Skinner's (1994) argument that the dollar values of damages in securities litigation are a positive function of firm size. The relation between disclosure and the number of analysts following the firm (NUM_ANST) is also positive. The results are consistent with the finding of Lang and Lundholm (1996). It seems reasonable to expect that the more analysts following the firm, the 
higher the level of information disclosure because security analysts frequently ask managers to collect information that they then analyze and publish. Our results reveal, however, that empirical associations between disclosure and return variables, such as the market adjusted return (AR_bf6m), the return-earnings correlation (RE), and return volatility (STD10YR), are weak. The empirical associations between disclosure and the ownership variables of INSTI, BLOCK, and INSIDER are all weak. We also find that the ADTA is negatively associated with operating cash flow (OCF) and changes in performance (CROA). These results support the Dechow's (1994) finding that discretionary accruals are negatively correlated with operating cash flows. The negative relation between the ADTA and CROA supports the finding of Burgstahler and Dichev (1997) that earnings are managed to avoid losses and negative changes in earnings.

\section{Long-term, post-issue SEO return performance}

To examine the long-term effect of socially responsible and ethical decisions on postissue performance, we examine the long-term return performance for up to five years after a SEO. For that task, we first classify our total sample into four groups. In particular, if the average percentile rank of the number of press releases per six-month period over $M(-4)$ through $M(+3)$, the DL, is greater than the third quartile value and the ADTA is greater than or equal to the median value, then the sample is assigned to group 1. If the DL is greater than the third quartile value and the ADTA is less than the median value, then the sample is classified as belonging to group 2 (ethical firms choosing high disclosure). If the DL is less than the first quartile value and the ADTA is greater than or equal to the median value, then the sample is classified as belonging to group 3 (unethical firms choosing low disclosure). If the DL is less than the first quartile value 
and the ADTA is less than the median value, then the firm is assigned to group 4. According to our convention, groups 1 and 3 are unethical firms and groups 2 and 4 are ethical firms. Groups 1 and 2 include firms with socially responsible disclosure levels and groups 3 and 4 include firms with socially irresponsible disclosure levels. Our major interest of comparison is firms with ethical reporting that choose persistent disclosure vs. firms with unethical reporting that choose low disclosure.

We then follow the Fama \& French (1993) three-factor model approach and run the regression for individual securities in each group. Table 4 presents the post-issue returns up to five years after the $\mathrm{Q}(+2)$ earnings announcement.

\section{[Insert Table IV about here.]}

Buy-and-hold returns are market-adjusted returns compounded daily over the one-year period after the $\mathrm{Q}(+2)$ earnings announcement. The three-factor model $\alpha$ coefficients are alphas from the Fama \& French three-factor model estimated over 12- to 60 -month periods after the $\mathrm{Q}(+2)$ earnings announcement. Panel A reports the one-year post-issue returns based upon buy-andhold returns and three-factor model $\alpha$ coefficients for up to five years for various groups. Panel B reports the results of the difference tests of long-term, post-issue returns across the various groups.

Interestingly, evidence suggests that firms with high disclosure and low earnings management (group 2) perform significantly better than firms with low disclosure and high earnings management (group 3) over the five-year period. For instance, the means of the monthly abnormal returns estimated over 12 and 60 months for group 2, based upon the Fama \& French three-factor model, are higher (less negative) than those of group 3 by $16.88 \%$ and $14.76 \%$ per 
year, respectively. ${ }^{9}$ In addition, over the five-year period, firms with high disclosure and high earnings management (group 1) have consistently higher $\alpha$ coefficients than those of firms with low disclosure and high earnings management. For example, the means of monthly $\alpha$ coefficients estimated over 12 and 60 months for group 1 are higher than those of group 3 by $6.58 \%$ and $14.09 \%$ per year, respectively. These results indicate that firms with extensive disclosure substantially reduce their post-issue SEO underperformance over the long run. Our unreported analysis suggests that these results remain qualitatively similar with slightly weaker significance when we use different cut-off points, such as medians for both variables of DL and ADTA.

From these results, we maintain that the impact of voluntary disclosure lasts for a substantial time period because the information effect alone cannot sustain significant differences in returns among groups for up to five years after a SEO. However, there is no significant difference between firms with high disclosure and high earnings management (group 1) and firms with high disclosure and low earnings management (group 2). It seems that among high-disclosure firms, earnings management alone does not change long-term, post-issue performance. These results are understandable because investors can see through earnings management after the offering when enough information is revealed through persistent and frequent, transparency-increasing disclosures. In addition, comparison between groups 3 and 4 suggests that when disclosure level is relatively low, post-offering SEO underperformance is more severe when earnings management is aggressive. Overall, the evidence from the

\footnotetext{
${ }^{9}$ We calculate the post-issue annual return differences between groups 2 and 3 based upon the numbers reported in Panel A of Table 4 as follows: $[(-0.00572)-(-0.01979)] \times 12=0.1688$ and $[(-0.00063)-(-0.01293)] \times 12=0.1476$. Similarly, we compute the post-issue annual return differences between groups 1 and 3 as $[(-0.01431)-(-0.01979)]$ x $12=0.0658$ and $[(-0.00119)-(-0.01293)] \times 12=0.1409$.
} 
comparisons between group 1 and group 3, between group 2 and group 3, and between groups 3 and 4 are consistent with our monitoring hypothesis.

However, the difference tests of high- and low-disclosure firms among firms with low earnings management (i.e., group 2 and group 4) suggest insignificant results. While the explanations regarding the insignificant difference between groups 2 and 4 are not readily apparent, we conjecture that when earnings management is relatively low, the impact of disclosure on post-offering performance is not substantial, presumably because the post-issue underperformance of firms with conservative earnings management is not severe.

Disclosure made in different periods might affect equity offering firms' earnings manipulation differently. To check the robustness of our results taking the timing differences into account, we classify our total sample into four groups based on average percentile rank of the number of press releases per six-month period over the $M(-4)$ through $M(0)$ period (before the offering) instead of $\mathrm{M}(-4)$ through $\mathrm{M}(+3)$ (around the offering).

\section{[Insert Table V about here.]}

The results reported in Table V suggest that the results from the comparison between group 1 and group 3 based upon $\mathrm{M}(-4)$ through $\mathrm{M}(0)$ period remain significant over 3, 4, and 5 years. In addition, the results from the comparison between group 2 and group 3 remain significant over 1, 2, 4, and 5 years after a SEO and comparison between groups 3 and 4 shows significant difference over 2, 3, 4, and 5 years after a SEO. Although the results from the M(-4) through $\mathrm{M}(0)$ period seem slightly weaker than the results from the $\mathrm{M}(-4)$ through $\mathrm{M}(+3)$ period, they are still significant up to five years. Insignificant results of the difference tests between group 
1 and group 2 and between group 2 and group 4 remain the same over the $M(-4)$ through $M(0)$ period.

While it is not completely possible to distinguish the information effect from the monitoring effect, the information effect alone cannot last for up to five years after a SEO. Fama's (1970) efficient market hypothesis suggests that stock prices fully reflect all relevant information instantaneously, and it is difficult for anyone to consistently outperform the market averages. Consequently, we claim that the evidence of long-term, post-issue SEO performance supports the monitoring explanation and the view that corporate conduct grounded in social responsibility and ethical decisions eventually pays.

\section{Additional tests}

The previous section shows that based upon the Fama \& French (1993) three-factor model, the long-term underperformance of SEOs is significantly lower for ethical firms choosing extensive disclosure than unethical firms choosing low disclosure. To examine the impact of disclosure and earnings management on long-term SEO performance further, we perform the following additional regressions.

We run regressions using post-issue returns up to five years after $\mathrm{Q}(+2)$ earnings announcement as dependent variables and DL, ADTA, and other firm characteristics including firm size (SIZE), book-to-market ratio (BM), and leverage (LEV) as the explanatory variables. Our results reported in Panel A of Table VI show that the coefficients on ADTA are significant and negative over all five estimation periods. While positive over all five estimation periods, the coefficients on DL are significant in the regressions estimated over 12-, 24- and 60-month periods. The coefficients on SIZE are all significantly positive while the coefficients on BM and 
LEV are mostly insignificant except that of $\mathrm{BM}$ estimated over 12 months. We also run regressions using post-issue returns up to five years after $Q(+2)$ earnings announcement as dependent variables and various interaction dummy variables representing four groups in Table IV and other firm characteristics variables of SIZE, BM, and LEV as the explanatory variables. The intercept represents the returns for the firms in the middle two quartiles (second and third quartiles) of disclosure distribution, and therefore the coefficients on group dummy variables can be understood as the difference between returns for a specific group and returns for this base group. The results reported in Panel B suggest that consistent with the results reported in Table IV, the coefficient on the group dummy representing low disclosure-high earnings management firms (LDL_HEM) is most negative and statistically significant over all estimation windows except the first year. The coefficient on high disclosure and low earnings management group (HDL_LEM) is positive, but significant only in the first year. The coefficients on high disclosure and high earnings management group (HDL_HEM) and those on low disclosure and low earnings management group (LDM_LEM) are insignificant. Combined together, these results suggest that the market penalty over the long-term is most substantial for the firms with aggressive earnings management and socially irresponsible disclosure (LDL_HEM), supporting our monitoring hypothesis (b).

\section{Conclusions}

In this article, we address complex issues of ethics and disclosure using a sample of seasoned equity offering firms. We attempt to examine these complicated matters from the viewpoint of three academic areas, including business ethics, accounting, and finance. Specifically, we examine whether socially responsible disclosure decisions of seasoned equity 
offering firms and unethical earnings manipulations are endogenously determined. We also examine whether the long-term, equity market values SEO firms' socially responsible and ethical decisions. We maintain that the relations among ethics, disclosure, and long-term financial performance can be understood when we view socially responsible issuing firms as those with extensive voluntary disclosure and ethical firms as firms with limited earnings management.

We find that disclosure is endogenously determined and negatively associated with earnings management and vice versa. Our findings support the premise that extensive disclosure reduces information asymmetry, exposes unethical earnings manipulation, and therefore, reduces the incentive to manage earnings in SEO firms.

While the theory of agency and disclosure has been perhaps one of the most important areas in the study of corporate finance and accounting, direct empirical evidence on the issue is scarce. In particular, only a few studies examine the effect of disclosure on corporate performance. In this study, we provide evidence on this issue. Specifically, we find that socially responsible disclosure activities around the announcement of a SEO positively affect long-term, post-issue performance. Interestingly, we find that ethical firms disclosing extensively provide considerably higher returns than firms managing their earnings but disclosing less, even up to five years after a SEO. We interpret this evidence to mean that the information effect alone is not sufficient to explain long-term, post-offering performance issues. Instead, we maintain that the effect of monitoring on post-issue performance lasts for a long period of time and that the financial market values corporate efforts toward social responsibility.

These findings support the notion that greater disclosure helps reduce information asymmetry, enhances the transparency of earnings by increased monitoring, reduces agency costs from the separation of ownership and control, and reduces long-term, post-issue SEO 
underperformance. The direction of this relation is consistent with the common intuition that corporate efforts to incorporate social responsibility, such as improving the transparency of the information environment through voluntary disclosure, will eventually improve firm performance. The results of this study also suggest that the supply of corporate information is determined, in part, by SEO firms' post-issue performance considerations, presumably due to their reputation concerns. 


\section{References}

Barnea, A., and A. Rubin: 2005, 'Corporate Social Responsibility as a Conflict between Shareholders', Working paper, University of Texas at Austin.

Barnett, M., and R. Salomon: 2006, 'Beyond Dichotomy: the Curvilinear Relationship between Social Responsibility and Financial Performance', Strategic Management Journal 27, 1101-1122

Becker, C.L., M. L. Defond, J. Jiambalvo, and K. Subramanyam: 1998, 'The Effect of Audit Quality on Earnings Management', Contemporary Accounting Research 15, 1-24.

Botosan, C.: 1997, 'Disclosure Level and the Cost of Equity Capital', Accounting Review 72, 305-333.

Burgstahler, D., and I. Dichev: 1997. 'Earnings Management to Avoid Earnings Decreases and Losses', Journal of Accounting and Economics 24, 99-126.

Chung, K., and H. Jo: 1996, 'The Impact of Security Analysts' Monitoring and Marketing Functions on the Market Value of Firms', Journal of Financial \& Quantitative Analysis 31, 493-512.

Dechow, P.: 1994, 'Accounting Earnings and Cash Flows as Measures of Firm Performance: the Role of Accounting Accruals', Journal of Accounting and Economics 18, 3-42.

DuCharme L., P. Malatesta, and S. Sefcik: 2004, 'Earnings Management, Stock Issues, and Shareholder Lawsuits', Journal of Financial Economics 71, 27-49.

Fama, E.F.: 1970, 'Efficient Capital Markets: A Review of Theory and Empirical Work', Journal of Finance 25, 383-417.

Fama, E.F., and K. French: 1993, 'Common Risk Factors in the Returns on Stocks and Bonds', Journal of Financial Economics 33, 3-56.

Friedman, M.: 1970, 'Money and Income: Comment on Tobin', Quarterly Journal of Economics 84 (2), 318-327.

Gelb, D., and J. Strawer: 2001, 'Corporate Social Responsibility and Financial Disclosures: An Alternative Explanation', Journal of Business Ethics 33, 1-33.

Hamilton, S., H. Jo, and M. Statman: 1993, 'Doing Well While Doing Good? The Investment Performance of Socially Responsible Mutual Funds', Financial Analyst Journal 49 (6), 62-66.

Hartzell, J.C., and L. Starks: 2003. 'Institutional Investors and Executive Compensation', Journal of Finance 58, 2351-2374.

Healy, P. and J. Wahlen: 1999, 'A Review of the Earnings Management Literature and Its Implications for Standard Setting', Accounting Horizons 13, 365-383.

Hellsten, S., and C. Mallin: 2006, "Are "Ethical" or "Socially Responsible" Investments Socially Responsible?', Journal of Business Ethics 66, 393-406.

Hill, R. P., T. Ainscough, T. Shank, and D. Manullang: 2007, 'Corporate Social Responsibility and Socially Responsible Investing: A Global Perspective', Journal of Business Ethics 70, 165-174. 
Hribar P., and D. Collins: 2002, 'Errors in Estimating Accruals: Implications for Empirical Research', Journal of Accounting Research 40, 105-134.

Jensen, M., and W. Meckling: 1976, 'Theory of the Firm, Managerial Behavior, Agency Costs and Ownership Structure', Journal of Financial Economics 3, 305-360.

Jo, H., and Y. Kim: 2007, 'Disclosure Frequency and Earnings Management', Journal of Financial Economics, forthcoming.

Jones, J.: 1991, 'Earnings Management during Import Relief Investigations', Journal of Accounting Research 29, 193-228.

King, R., G. Pownall, and G. Waymire: 1990, 'Expectations Adjustment via Timely Management Forecasts: Review, Synthesis, and Suggestions for Future Research. Journal of Accounting Literature 9, 113-144.

Kothari, S.P., A. J. Leone, and C. Wasley: 2005, 'Performance Matched Discretionary Accrual Measures', Journal of Accounting and Economics 39, 163-197.

Kreander, N., R. Gray, D. Power, and C. Sinclair: 2005, 'Evaluating the Performance of Ethical and Nonethical Funds: A Matched Pair Analysis', Journal of Business Finance and Accounting 32, 1465 1493.

Lang, M.H., and R. Lundholm: 1993, 'Cross-sectional Determinants of Analyst Ratings of Corporate Disclosures', Journal of Accounting Research 31, 246-271.

Lang, M.H., and R. Lundholm: 1996, 'Corporate Disclosure Policy and Analysts Behavior', Accounting Review 71, 467-492.

Lang, M.H., and R. Lundholm: 2000, 'Voluntary Disclosure and Equity Offerings: Reducing Information Asymmetry or Hyping the Stock?', Contemporary Accounting Research, 623-662.

Loughran, T., and J. Ritter: 1995, 'The New Issues Puzzle', Journal of Finance 50, 23-51.

Loughran, T., and J. Ritter: 1997, 'The Operating Performance of Firms Conducting Seasoned Equity Offerings', Journal of Finance 52, 1823-1850.

Margolis, J. D., and J. P. Walsh: 2003, 'Misery Loves Companies: Rethinking Social Initiatives by Business', Administrative Science Quarterly 48, 268-305.

Merton, R.: 1987, 'A Simple Model of Capital Market Equilibrium with Incomplete Information', Journal of Finance 42, 483-510.

McWilliams, A., and D. Siegel: 2001, 'Corporate Social Responsibility and Firm Financial Performance: Correlation or Misspecification?’, Strategic Management Journal 21, 603-609.

Modigliani, F., and M. Miller: 1958, 'The Cost of Capital, Corporation Finance and the Theory of Investment', American Economic Review 48, 261-297.

Navarro, P.: 1988, 'Why do Corporations Give to Charity?', Journal of Business 61, 65-93. 
Oberman, W.D.: 2000, Book Review of Mitchell: 'The Conspicuous Corporation', (1997), Business and Society 329, 239-244.

Orlitzky, M., F. L. Schmidt and S. L. Rynes: 2003, 'Corporate Social and Financial Performance: A Meta Analysis', Organizational Studies 24, 403-441.

Rangan, S.: 1998, 'Earnings Management and the Performance of Seasoned Equity Offerings', Journal of Financial Economics 50, 101-122.

Schipper, K.: 1989, 'Commentary on Earnings Management', Accounting Horizons 3, 91-102.

Skinner, D.J.: 1994, 'Why Firms Voluntarily Disclose Bad News', Journal of Accounting Research 32, $38-60$.

Skinner, D.J.: 1997. 'Earnings Disclosure and Stockholder Lawsuits', Journal of Accounting and Economics 23, 249-282.

Small, A., and J. Zivin: 2002, 'A Modigliani-Miller Theory of Corporate Social Responsibility', Columbia University mimeo.

Spiess, D.K., and J. Affleck-Graves: 1995, 'Underperformance in Long-Run Stock Returns Following Seasoned Equity Offerings', Journal of Financial Economics 38, 243-267.

Statman, M.: 2000, ‘Socially Responsible Mutual Funds', Financial Analyst Journal 56 (3), 30-39.

Teoh S.H., I. Welch, and T. Wong: 1998a, 'Earnings Management and the Underperformance of Seasoned Equity Offerings', Journal of Financial Economics 50, 63-99.

Teoh, S.H., I. Welch and T. J. Wong: 1998b, 'Earnings Management and the Long-Run Market Performance of Initial Public Offerings', Journal of Finance 53, 1935-1974.

Tsoutsoura, M.: 2004, 'Corporate Social Responsibility and Financial Performance', Working paper, Center for Responsible Business, Haas School of Business, University of California at Berkeley.

Van De Ven, B., and R, Jurissen: 2005, 'Competing Responsibly’, Business Ethics Quarterly 15, 299317.

Webb, N.: 1996, 'Corporate Profits and Social Responsibility: "Subsidization” of Corporate Income under Charitable Giving Tax Laws', Journal of Economics and Business 48, 401-421.

Wood, D. J. and R. E. Jones: 1995, 'Stakeholder Mismatching: A Theoretical Problem in Empirical Research on Corporate Social Performance', International Journal of Organizational Analysis 3, 229-267. 


\section{Appendix A: Calculation of disclosure level (DL)}

We first obtain the number of press releases for each six-month period around SEO announcement by searching DJI database system. To obtain a measure of disclosure comparable across time periods, we convert the number of press releases to average percentile rank. We show an example below.

Observation \#1

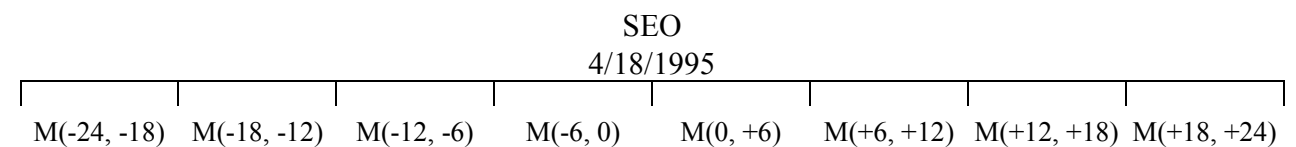

6 month periods $\mathrm{M}(-24,-18) \quad \mathrm{M}(-18,-12) \quad \mathrm{M}(-12,-6) \quad \mathrm{M}(-6,0) \quad \mathrm{M}(0,+6) \quad \mathrm{M}(+6,+12) \quad \mathrm{M}(+12,+18) \mathrm{M}(+18,+24)$

Calendar year assigned for the annual ranking Number of PRs

$\begin{array}{cccccccc}1993 & 1994 & 1994 & 1995 & 1995 & 1996 & 1996 & 1997 \\ 8 & 6 & 9 & 10 & 9 & 11 & 12 & 11\end{array}$

Observation \#2

6 month periods Calendar year assigned for the annual ranking Number of PRs

\begin{tabular}{c|c|c|c|c|c|c|c|}
\multicolumn{8}{c|}{ SEO } \\
\multicolumn{8}{|c|}{$9 / 7 / 1995$} \\
$\mathrm{M}(-24,-18)$ & $\mathrm{M}(-18,-12)$ & $\mathrm{M}(-12,-6)$ & $\mathrm{M}(-6,0)$ & $\mathrm{M}(0,+6)$ & $\mathrm{M}(+6,+12)$ & $\mathrm{M}(+12,+18)$ & $\mathrm{M}(+18,+24)$ \\
1993 & 1994 & 1994 & 1995 & 1995 & 1996 & 1996 & 1997 \\
22 & 21 & 24 & 30 & 28 & 32 & 33 & 33
\end{tabular}

Observation \#3

SEO

6 month periods

$$
\mathrm{N}
$$

for the annual ranking

Number of PRs

\begin{tabular}{c|cc|c|c|c|c|c|}
\multicolumn{8}{c}{ SEO } \\
\multicolumn{8}{|c|}{} \\
\hline $\mathrm{M}(-24,-18)$ & $\mathrm{M}(-18,-12)$ & $\mathrm{M}(-12,-6)$ & $\mathrm{M}(-6,0)$ & $\mathrm{M}(0,+6)$ & $\mathrm{M}(+6,+12)$ & $\mathrm{M}(+12,+18) \mathrm{M}(+18,+24)$ \\
& & & & & & & \\
1994 & 1995 & 1995 & 1996 & 1996 & 1997 & 1997 & 1998 \\
6 & 6 & 6 & 9 & 8 & 9 & 9 & 8
\end{tabular}

Observation \#4

6 month periods

calendar year assigned

for the annual ranking

Number of PRs

\begin{tabular}{|c|c|c|c|c|c|c|c|}
\multicolumn{8}{c}{ SEO } \\
\multicolumn{10}{c|}{$11 / 3 / 1997$} \\
$\mathrm{M}(-24,-18)$ & $\mathrm{M}(-18,-12)$ & $\mathrm{M}(-12,-6)$ & $\mathrm{M}(-6,0)$ & $\mathrm{M}(0,+6)$ & $\mathrm{M}(+6,+12)$ & $\mathrm{M}(+12,+18)$ & $\mathrm{M}(+18,+24)$ \\
& & & & & & & 1998 \\
1995 & 1996 & 1996 & 1997 & 1997 & 1998 & 1998 & 1999 \\
13 & 13 & 14 & 17 & 15 & 18 & 18 & 19
\end{tabular}

Number of PRs annual rank annual percentile rank ${ }^{*}$

1996 PRs from Observation \#1 M(+6, +12)

from Observation \#1 $\mathrm{M}(+12,+18)$

from Observation \#2 $\mathrm{M}(+6,+12)$

from Observation \#2 $\mathrm{M}(+12,+18)$

from Observation \#3 M(-6, 0)

from Observation \#3 $\mathrm{M}(0,+6)$

from Observation \#4 M(-18, -12)

from Observation \#4 M(-12, -6)
11

12

32

33

9

8

13

14

Number of samples in 1996:

8
0.2857

0.4286

0.8571

1

0.1486

0

0.5714

0.7143

* (annual rank-1) / (number of samples each year - 1)

This Appendix A is borrowed from Jo and Kim (2007). 
TABLE I

Sample characteristics of seasoned equity offerings

Panel A: Time Distribution

\begin{tabular}{rrrrr} 
Year & Freq & $\%$ & Cum Freq & $\%$ \\
\hline \hline 1990 & 83 & 5.80 & 83 & 5.80 \\
1991 & 190 & 13.28 & 273 & 19.08 \\
1992 & 173 & 12.09 & 446 & 31.17 \\
1993 & 200 & 13.98 & 646 & 45.15 \\
1994 & 149 & 10.41 & 795 & 55.56 \\
1995 & 189 & 13.21 & 984 & 68.77 \\
1996 & 231 & 16.14 & 1,215 & 84.91 \\
1997 & 216 & 15.09 & 1,431 & 100.00
\end{tabular}

Panel B: Size characteristics

\begin{tabular}{|c|c|c|c|c|c|}
\hline & Mean & STD & Median & First quartile & Third Quartile \\
\hline Total assets & 9987.5879 & $3,641.0980$ & 146.2965 & 433.3660 & 54544.4810 \\
\hline Market value of equity & 780.3003 & $2,907.0380$ & 199.8094 & 81.8935 & 611.3351 \\
\hline Book value of equity & 291.8861 & 918.6333 & 62.1460 & 19.3850 & 202.5740 \\
\hline
\end{tabular}

Panel C: Offer Characteristics

\begin{tabular}{lrrrrr} 
& Mean & STD & Median & First quartile & Third Quartile \\
\hline \hline Offer amount & 81.1986 & 131.9153 & 42.7880 & 19.2000 & 90.0000 \\
Offer size & 0.2607 & 0.3212 & 0.1901 & 0.1125 & 0.3096 \\
Offer size (in amounts) & 0.2972 & 0.3830 & 0.2010 & 0.1158 & 0.3549
\end{tabular}

This table summarizes our sample of 1,431 seasoned equity offerings of common stock by US industrial firms over the period 1990 through 1997. We terminate our sample in 1997 in order to examine post-offering returns up to five years after the offerings, i.e., up to 2002. The total assets, market value of equity and book value of equity are measured at the end of the quarter before the offering announcement. The total assets, market value of equity, book value of equity and offer amount are measured in millions of dollars. Offer size is measured as the number of shares offered divided by the number of pre-offering shares outstanding. Offer size (in amounts) is measured as the offer amount divided by the market value of equity. 
TABLE II

Bivariate correlations

DL ADTA ROA CROA AR_bf6m SIZE RE STD10yr NUM_ANST NONB6

\begin{tabular}{|c|c|c|c|c|c|c|c|c|c|c|c|c|}
\hline ADTA & $-0.0853 * *$ & & & & & & & & & & & \\
\hline ROA & -0.0288 & $-0.0979 * *$ & & & & & & & & & & \\
\hline CROA & 0.0041 & $0.0911 * *$ & $-0.7647 * * *$ & & & & & & & & & \\
\hline AR_bf6m & -0.0259 & 0.0299 & $0.1129 * * *$ & $-0.0761 * * *$ & & & & & & & & \\
\hline SIZE & $0.4711 * * *$ & $-0.1311 * * *$ & $0.1879 * * *$ & $-0.0865 * * *$ & 0.0316 & & & & & & & \\
\hline $\mathrm{RE}$ & 0.0043 & -0.0180 & $0.1731 * * *$ & $-0.0740 * *$ & 0.0249 & -0.0441 & & & & & & \\
\hline STD10YR & -0.0459 & 0.0179 & -0.0338 & -0.0433 & $0.4533 * * *$ & $-0.1576 * * *$ & $0.0501 *$ & & & & & \\
\hline NUM_ANST & $0.4326 * * *$ & $-0.1017 * * *$ & $0.1369 * * *$ & $-0.0607 * *$ & $-0.0793 * * *$ & $0.6775 * * *$ & $-0.0530 *$ & $-0.1613 * * *$ & & & & \\
\hline $\mathrm{OCF}$ & 0.0318 & $-0.3205 * * *$ & $0.7710 * * *$ & $-0.5169 * * *$ & $0.0872 * * *$ & $0.2606 * * *$ & $0.2136 * * *$ & $-0.0555 *$ & $0.2039 * * *$ & & & \\
\hline LEV & 0.0224 & 0.0128 & 0.0005 & 0.0123 & $-0.0485 *$ & -0.0104 & 0.0227 & -0.0111 & 0.0327 & 0.0128 & & \\
\hline NONB6 & $-0.1159 * * *$ & $0.1189 * * *$ & -0.0116 & 0.0066 & $-0.0620 * *$ & $-0.1830 * * *$ & 0.0186 & -0.0084 & $-0.1229 * * *$ & $-0.0867 * * *$ & 0.0075 & \\
\hline ABSTACC & $-0.0769 * *$ & $0.1342 * * *$ & $-0.5155 * * *$ & $0.5246 * * *$ & 0.0030 & $-0.2035 * * *$ & -0.0160 & $0.0565 *$ & $-0.1536 * * *$ & $-0.4155^{* * *}$ & 0.0002 & $0.1369 * * *$ \\
\hline
\end{tabular}

This table shows pearson correlation coefficients among select variables. ADTA is annualized performance adjusted discretionary total accruals over the period $\mathrm{Q}(-1)$ through $\mathrm{Q}(+2)$ scaled by lagged total assets. DTA is annualized discretionary total accruals over the period $\mathrm{Q}(-1)$ through $\mathrm{Q}(+2)$ scaled by lagged total assets. Panel B presents pearson correlation coefficients among variables used in the regression analyses. DL: average percentile rank of the number of press releases per six-month period over $\mathrm{M}(-4)$ through $\mathrm{M}(+3)$; ADTA: annualized performance adjusted discretionary total accruals over the period $\mathrm{Q}(-1)$ through $\mathrm{Q}(+2)$ scaled by lagged total assets; ROA: annualized ROA measured as income before extraordinary items summed over $\mathrm{Q}(-1)$ to $\mathrm{Q}(+2)$ and scaled by assets at the beginning of $\mathrm{Q}(-1)$; CROA: changes in annualized ROA measured as income before extraordinary items summed over $\mathrm{Q}(+3)$ to $\mathrm{Q}(+6)$ and scaled by assets at the beginning of $\mathrm{Q}(+3)$ - income before extraordinary items summed over $\mathrm{Q}(-1)$ to $\mathrm{Q}(+2)$ and scaled by assets at the beginning of $\mathrm{Q}(-1)$; AR bf6m: marketadjusted returns over one-year period ending 6 months before the offering announcement. Market-adjusted returns are computed by subtracting the return on the value-weighted market index from firm returns; SIZE: $\log$ of the market value of equity at Q(-1); RE: annual return/earnings correlation measured over the10 year period before the offering announcement; STD10YR: standard deviation of market-adjusted returns over 10 years prior to the offering announcement; NUM_ANST: the number of analysts' following; OCF: operating cash flows over the period Q(-1) through Q(+2) scaled by the lagged total assets; LEV: debtto-equity ratio, the proxy for the closeness to the violation of lending contracts; NONB6: indicator variable, which is set to equal 1 if the firm's auditor is not one of big six accounting firms, and 0 otherwise; ABSTACC: absolute value of total accruals over the period Q(-1) through Q(+2) scaled by the lagged total assets.

$* * *, * *, *$ significance at the $1 \%, 5 \%$, and $10 \%$ levels, respectively. 
TABLE III

Regression results of simultaneous equation model of disclosure and earnings management

\begin{tabular}{|c|c|c|c|c|c|c|c|c|}
\hline \multirow{2}{*}{$\begin{array}{l}\text { Independent } \\
\text { variables } \\
\text { Intercept }\end{array}$} & \multicolumn{3}{|c|}{$\begin{array}{l}\text { Dependent variable: DL } \\
\text { Full sample }\end{array}$} & \multicolumn{5}{|c|}{$\begin{array}{l}\text { Dependent variable: DL } \\
\text { With positive ADTA only }\end{array}$} \\
\hline & 0.19432 & & 0.14707 & & 0.15482 & & 017255 & \\
\hline & (4.15) & $* * *$ & $(4.50)$ & $* * *$ & $(2.41)$ & $* *$ & (3.54) & $* * *$ \\
\hline \multirow[t]{2}{*}{ ADTA } & -0.37151 & & -0.37184 & & -0.40354 & & -0.29466 & \\
\hline & $(-3.37)$ & $* * *$ & $(-4.56)$ & $* * *$ & $(-2.70)$ & $* * *$ & $(-2.27)$ & $* *$ \\
\hline \multirow[t]{2}{*}{ ROA } & -0.26848 & & -0.25830 & & -0.29627 & & -0.30051 & \\
\hline & $(-5.86)$ & $* * *$ & $(-7.22)$ & $* * *$ & $(-4.54)$ & $* * *$ & $(-5.40)$ & $* * *$ \\
\hline \multirow[t]{2}{*}{ CROA } & -0.13849 & & -0.17715 & & -0.13259 & & -0.19665 & \\
\hline & $(-2.14)$ & $* *$ & $(-3.32)$ & $* * *$ & $(-1.40)$ & & $(-2.51)$ & $* * *$ \\
\hline \multirow[t]{2}{*}{ AR_bf6m } & -0.00801 & & & & 0.00171 & & & \\
\hline & $(-0.82)$ & & & & $(0.14)$ & & & \\
\hline \multirow[t]{2}{*}{ SIZE } & 0.05637 & & 0.06123 & & 0.06693 & & 0.05804 & \\
\hline & (6.00) & $* * *$ & $(9.33)$ & $* * *$ & $(5.15)$ & $* * *$ & (6.16) & $* * *$ \\
\hline \multirow[t]{2}{*}{$\mathrm{RE}$} & 0.00713 & & & & 0.00170 & & & \\
\hline & $(0.46)$ & & & & $(0.09)$ & & & \\
\hline \multirow[t]{2}{*}{ STD10YR } & 0.01079 & & & & 0.02811 & & & \\
\hline & $(0.61)$ & & & & (1.32) & & & \\
\hline \multirow[t]{2}{*}{ INSTI } & -0.06901 & & & & -0.09910 & & & \\
\hline & $(-1.25)$ & & & & $(-1.31)$ & & & \\
\hline \multirow[t]{2}{*}{ BLOCK } & -0.02403 & & & & -0.01194 & & & \\
\hline & $(-0.59)$ & & & & $(-0.23)$ & & & \\
\hline \multirow[t]{2}{*}{ INSIDER } & -0.00129 & & & & 0.02894 & & & \\
\hline & $(-0.02)$ & & & & $(0.41)$ & & & \\
\hline \multirow[t]{2}{*}{ NUM_ANST } & 0.00558 & & 0.00419 & & 0.00415 & & 0.00587 & \\
\hline & (2.84) & $* * *$ & $(2.82)$ & $* * *$ & (1.56) & & (2.70) & $* * *$ \\
\hline \multirow{2}{*}{$\begin{array}{l}\text { Independent } \\
\text { variables }\end{array}$} & \multirow{2}{*}{\multicolumn{3}{|c|}{ Dependent variable: ADTA }} & & \multirow{2}{*}{\multicolumn{3}{|c|}{$\begin{array}{l}\text { Dependent variable: ADTA } \\
\text { With positive ADTA only }\end{array}$}} & \\
\hline & & & & & & & & \\
\hline \multirow[t]{2}{*}{ Intercept } & 0.06415 & & 0.08371 & & 0.07588 & & 010283 & \\
\hline & (1.11) & & (1.91) & $*$ & (1.13) & & $(2.22)$ & $* *$ \\
\hline \multirow[t]{2}{*}{ DL } & -0.65433 & & -0.82955 & & -0.61231 & & -0.59262 & \\
\hline & $(-3.91)$ & $* * *$ & $(-4.83)$ & $* * *$ & $(-2.39)$ & $* *$ & $(-3.08)$ & $* * *$ \\
\hline OCF & -0.30236 & & -0.31391 & & -0.30061 & & -0.32084 & \\
\hline & $(-6.28)$ & $* * *$ & $(-7.24)$ & $* * *$ & $(-4.90)$ & $* * *$ & $(-6.51)$ & $* * *$ \\
\hline CROA & -0.12401 & & -0.18156 & & -0.1753 & & -0.20115 & \\
\hline & $(-1.90)$ & $*$ & $(-3.04)$ & $* * *$ & $(-1.92)$ & $*$ & $(-2.89)$ & $* * *$ \\
\hline SIZE & 0.05589 & & 0.06315 & & 0.05651 & & 0.04369 & \\
\hline & (4.14) & $* * *$ & $(4.67)$ & $* * *$ & $(2.56)$ & $* *$ & $(2.73)$ & $* * *$ \\
\hline LEV & -0.00057 & & 0.00014 & & 0.00105 & & 0.00009 & \\
\hline & $(-0.60)$ & & $(0.41)$ & & $(0.37)$ & & $(0.28)$ & \\
\hline INSTI & -0.00924 & & & & -0.14705 & & & \\
\hline & $(-1.70)$ & $*$ & & & $(-2.06)$ & $* *$ & & \\
\hline BLOCK & -0.00193 & & & & -0.00809 & & & \\
\hline & $(-0.47)$ & & & & $(-0.16)$ & & & \\
\hline INSIDER & 0.00524 & & & & 0.05990 & & & \\
\hline & $(0.93)$ & & & & $(0.88)$ & & & \\
\hline NONB6 & -0.00889 & & 0.00471 & & 0.05551 & & 0.02976 & \\
\hline & $(-0.27)$ & & $(0.21)$ & & $(1.35)$ & & (1.08) & \\
\hline ABSTACC & 0.01511 & & 0.43309 & & 1.60767 & & 2.05000 & \\
\hline & $(0.02)$ & & $(0.82)$ & & $(1.70)$ & $*$ & (2.89) & $* * *$ \\
\hline Number of observations & 459 & & 627 & & 272 & & 356 & \\
\hline System Weighted $R^{2}$ & $22.54 \%$ & & $26.43 \%$ & & $27.61 \%$ & & $29.68 \%$ & \\
\hline
\end{tabular}


This table reports the results of association tests between disclosure and discretionary accruals of SEO firms. The following equations are estimated using three-stage simultaneous equation system:

$$
\begin{aligned}
& \text { 1) } \mathrm{DL}=\mathrm{a}+\mathrm{b}_{1} \text { ADTA }+\mathrm{b}_{2} \text { ROA }+\mathrm{b}_{3} \mathrm{CROA}+\mathrm{b}_{4} \text { AR_bf6m }+\mathrm{b}_{5} \text { SIZE }+\mathrm{b}_{6} \mathrm{RE}+\mathrm{b}_{7} \text { STD10YR }+\mathrm{b}_{8} \text { INSTI } \\
& +b_{9} \text { BLOCK }+b_{10} \text { INSIDER }+b_{11} \text { NUM_ANST } \\
& \text { 2) } \mathrm{ADTA}=\mathrm{a}+\mathrm{b}_{1} \mathrm{DL}+\mathrm{b}_{2} \text { OCF }+\mathrm{b}_{3} \text { CROA }+\mathrm{b}_{4} \text { SIZE }+\mathrm{b}_{5} \mathrm{LEV}+\mathrm{b}_{6} \text { INSTI }+\mathrm{b}_{7} \text { BLOCK }+\mathrm{b}_{8} \text { INSIDER } \\
& +b_{9} \text { NONB6 }+b_{10} \text { ABSTACC }
\end{aligned}
$$

where DL: average percentile rank of the number of press releases per six-month period over $\mathrm{M}(-4)$ through $\mathrm{M}(+3)$; ADTA: annualized performance adjusted discretionary total accruals over the period $\mathrm{Q}(-1)$ through $\mathrm{Q}(+2)$ scaled by lagged total assets; ROA: annualized ROA measured as income before extraordinary items summed over $\mathrm{Q}(-1)$ to $\mathrm{Q}(+2)$ and scaled by assets at the beginning of $\mathrm{Q}(-1)$; CROA: changes in annualized ROA measured as income before extraordinary items summed over $\mathrm{Q}(+3)$ to $\mathrm{Q}(+6)$ and scaled by assets at the beginning of $\mathrm{Q}(+3)$ - income before extraordinary items summed over $\mathrm{Q}(-1)$ to $\mathrm{Q}(+2)$ and scaled by assets at the beginning of Q(-1); AR_bf6m: market-adjusted returns over one-year period ending 6 months before the offering announcement. Market-adjusted returns are computed by subtracting the return on the value-weighted market index from firm returns; SIZE: log of the market value of equity at Q(-1); RE: annual return/earnings correlation measured over the10 year period before the offering announcement; STD10YR: standard deviation of market-adjusted returns over 10 years prior to the offering announcement; INSTI: percentage ownership of institutional investors; BLOCK: percentage ownership of blockholders; INSIDER: percentage ownership of insiders; NUM_ANST: the number of analysts' following; OCF: operating cash flows over the period Q(-1) through $\mathrm{Q}(+2)$ scaled by the lagged total assets; LEV: debt-to-equity ratio, the proxy for the closeness to the violation of lending contracts; NONB6: indicator variable, which is set to equal 1 if the firm's auditor is not one of big six accounting firms, and 0 otherwise; ABSTACC: absolute value of total accruals over the period Q(-1) through Q(+2) scaled by the lagged total assets. $* * *, * * *$ significance at the $1 \%, 5 \%$, and $10 \%$ levels in two-sided significance tests, respectively. $\mathrm{t}$-values are in the parentheses. 
TABLE IV

Long term, post-issue return performance and difference tests over the $M(-4)$ through $M(+3)$ period

Panel A: post-issue returns

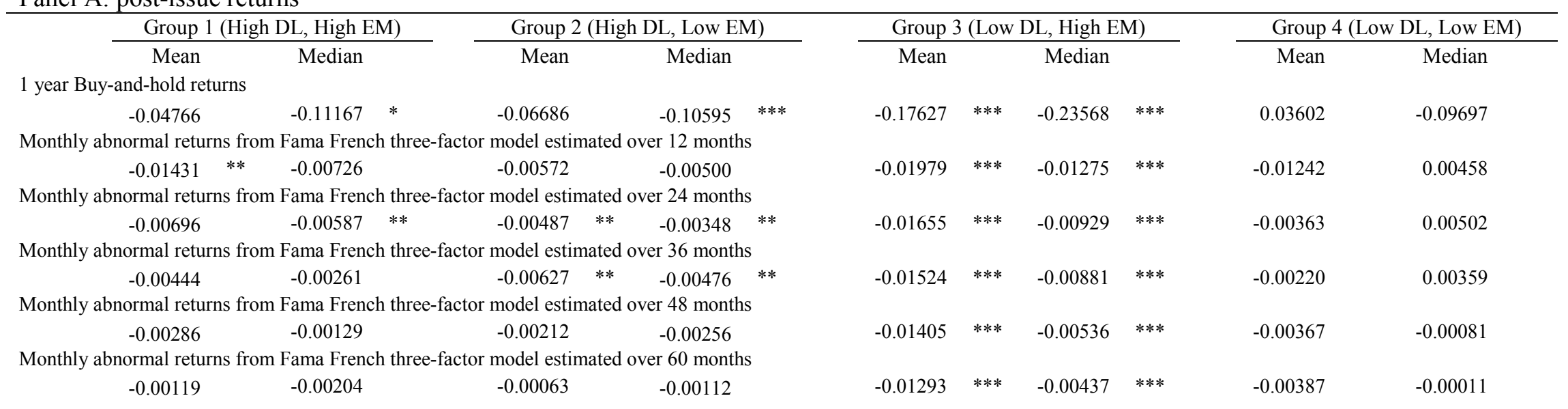

Panel B: P-values from the One-tailed T-tests between groups

1 year Buy-and-hold returns

Monthly abnormal returns from Fama French three-factor model estimated over 12 months

Monthly abnormal returns from Fama French three-factor model estimated over 24 months

Monthly abnormal returns from Fama French three-factor model estimated over 36 months

Monthly abnormal returns from Fama French three-factor model estimated over 48 months

Monthly abnormal returns from Fama French three-factor model estimated over 60 months

\begin{tabular}{|c|c|c|c|}
\hline Group 1 vs. 3 & Group 2 vs. 3 & Group 1 vs. 2 & Group 3 vs. 4 \\
\hline $0.0596^{*}$ & $0.0815^{*}$ & 0.4128 & $0.0278 * *$ \\
\hline 0.2732 & $0.0426^{* *}$ & 0.2788 & 0.2102 \\
\hline $0.0879^{*}$ & $0.0260 * *$ & 0.3451 & $0.0634^{*}$ \\
\hline $0.0426^{* *}$ & $0.0583^{*}$ & 0.3474 & $0.0522 *$ \\
\hline $0.0332 * *$ & $0.0191 * *$ & 0.4316 & $0.0974 *$ \\
\hline $0.0267 * *$ & $0.0149 * *$ & 0.4467 & 0.1236 \\
\hline
\end{tabular}

This table presents the post-issue returns up to five years after $\mathrm{Q}(+2)$ earnings announcement. Buy-and-hold returns are market-adjusted returns compounded daily over the one-year period after the $\mathrm{Q}(+2)$ earnings announcement. Three-factor model $\alpha$ coefficients are alphas from the Fama-French three-factor model estimated over 12 to 60 month periods after the $\mathrm{Q}(+2)$ earnings announcement. The following regression is estimated for each firm: $\left(R_{i t}-R_{f t}\right)=\alpha+b_{1}\left(R_{m t}-R_{f t}\right)+b_{2}$ $S M B_{t}+b_{3} H M L_{t}+e_{i t}$ where $\mathrm{R}_{\mathrm{it}}$ is monthly return of SEO firm in 12 to 60 month periods after the $\mathrm{Q}(+2)$ earnings announcement. ADTA: performance-adjusted annualized discretionary total accruals over the period $\mathrm{Q}(-1)$ through $\mathrm{Q}(+2)$ scaled by lagged total assets. Following Kothari, Leone and Wasley $(2005)$, we create a control sample based on ROA in the quarter before SEO announcement and industry (two-digit SIC code) for each offering. The ADTA for a SEO firm is the discretionary total accruals for that firm minus the discretionary total accruals of the matched non-SEO firm. If average percentile rank of the number of press releases per six-month period over $\mathrm{M}(-4)$ through $\mathrm{M}(+3)$ is greater than the third quartile value and ADTA is greater than or equal to the median value, then the sample is assigned into group 1. If average percentile rank of the number of press releases per six-month period over $\mathrm{M}(-4)$ through $\mathrm{M}(+3)$ is greater than the third quartile value and ADTA is less than the median value, then the sample is classified into group 2 . If average percentile rank of the number of press releases per six-month period over $M(-4)$ through $M(+3)$ is less than the first quartile value and ADTA is greater than or equal to the median value, then the sample is classified into group 3. If average percentile rank of the number of press releases per six-month period over $M(-4)$ through $M(+3)$ is less than the first quartile value and ADTA is less than the median value, then the sample is classified into group $4 . * * *, * *, *$ significant at the $1 \%$, $5 \%$, and $10 \%$ levels, respectively. 
TABLE V

Robustness check: Long term, post-issue return performance and difference tests over the $M(-4)$ through $M(0)$ period

Panel A: post-issue returns

\begin{tabular}{|c|c|c|c|c|c|c|c|c|c|}
\hline & Group 1 (High DL, High EM) & \multicolumn{2}{|c|}{ Group 2 (High DL, Low EM) } & \multicolumn{4}{|c|}{ Group 3 (Low DL, High EM) } & \multicolumn{2}{|c|}{ Group 4 (Low DL, Low EM) } \\
\hline Mean & Median & Mean & Median & Mean & & Median & & Mean & Median \\
\hline \multicolumn{10}{|c|}{1 year Buy-and-hold returns } \\
\hline-0.04393 & -0.09948 & -0.03056 & -0.07490 & -0.16558 & $* * *$ & -0.24334 & $* * *$ & 0.04500 & -0.05102 \\
\hline \multicolumn{10}{|c|}{ Monthly abnormal returns from Fama French three-factor model estimated over 12 months } \\
\hline-0.01235 & -0.00349 & -0.00416 & -0.00460 & -0.01400 & $* * *$ & -0.00730 & $* * *$ & -0.00948 & 0.00387 \\
\hline \multicolumn{10}{|c|}{ Monthly abnormal returns from Fama French three-factor model estimated over 24 months } \\
\hline-0.00452 & -0.00318 & -0.00378 & -0.00361 & -0.01152 & $* * *$ & -0.00696 & $* * *$ & -0.00095 & 0.00502 \\
\hline \multicolumn{10}{|c|}{ Monthly abnormal returns from Fama French three-factor model estimated over 36 months } \\
\hline-0.00238 & -0.00135 & -0.00510 & -0.00422 & -0.01019 & $* * *$ & -0.00604 & $* *$ & -0.00230 & 0.00165 \\
\hline \multicolumn{10}{|c|}{ Monthly abnormal returns from Fama French three-factor model estimated over 48 months } \\
\hline-0.02431 & -0.00156 & -0.00127 & -0.00344 & -0.00932 & $* *$ & -0.00372 & $* *$ & -0.00071 & -0.00081 \\
\hline \multicolumn{10}{|c|}{ Monthly abnormal returns from Fama French three-factor model estimated over 60 months } \\
\hline-0.00115 & -0.00020 & -0.00010 & -0.00106 & -0.00849 & ** & -0.00351 & $*$ & 0.00056 & 0.00305 \\
\hline
\end{tabular}

Panel B: P-values from the One-tailed T-tests between groups

1 year Buy-and-hold returns

Monthly abnormal returns from Fama French three-factor model estimated over 12 months

Monthly abnormal returns from Fama French three-factor model estimated over 24 months

Monthly abnormal returns from Fama French three-factor model estimated over 36 months

Monthly abnormal returns from Fama French three-factor model estimated over 48 months

Monthly abnormal returns from Fama French three-factor model estimated over 60 months

\begin{tabular}{c} 
Group 1 vs. 3 \\
\hline $0.0846^{*}$ \\
0.4261 \\
0.1438 \\
$0.0765^{*}$ \\
$0.0910^{*}$ \\
$0.0715^{*}$
\end{tabular}

\begin{tabular}{c} 
Group 2 vs. 3 \\
\hline $0.0631^{*}$ \\
$0.0650^{*}$ \\
$0.0652^{*}$ \\
0.1364 \\
$0.0413^{* *}$ \\
$0.0287^{*} *$
\end{tabular}

\begin{tabular}{cc} 
Group 1 vs. 2 & Group 3 vs. 4 \\
\hline & \\
0.4450 & $0.0223^{* *}$ \\
0.1764 & 0.2853 \\
0.4491 & $0.0586^{*}$ \\
0.2937 & $0.0998^{*}$ \\
0.3984 & $0.0829^{*}$ \\
0.4014 & $0.0722^{*}$
\end{tabular}

This table presents the post-issue returns up to five years after $\mathrm{Q}(+2)$ earnings announcement. Buy-and-hold returns are market-adjusted returns compounded daily over the one-year period after the $\mathrm{Q}(+2)$ earnings announcement. Three-factor model $\alpha$ coefficients are alphas from the Fama-French three-factor model estimated over 12 to 60 month periods after the $\mathrm{Q}(+2)$ earnings announcement. The following regression is estimated for each firm: $\left(R_{i t}-R_{f t}\right)=\alpha+b_{1}\left(R_{m t}-R_{f t}\right)+b_{2}$ $S M B_{t}+b_{3} H M L_{t}+e_{i t}$ where $\mathrm{R}_{\mathrm{it}}$ is monthly return of SEO firm in 12 to 60 month periods after the Q(+2) earnings announcement. ADTA: performance-adjusted annualized discretionary total accruals over the period $\mathrm{Q}(-1)$ through $\mathrm{Q}(+2)$ scaled by lagged total assets. Following Kothari, Leone and Wasley $(2005)$, we create a control sample based on ROA in the quarter before SEO announcement and industry (two-digit SIC code) for each offering. The ADTA for a SEO firm is the discretionary total accruals for that firm minus the discretionary total accruals of the matched non-SEO firm. If average percentile rank of the number of press releases per six-month period over $\mathrm{M}(-4)$ through $\mathrm{M}(0)$ is greater than the third quartile value and ADTA is greater than or equal to the median value, then the sample is assigned into group 1 . If average percentile rank of the number of press releases per six-month period over $M(-4)$ through $M(0)$ is greater than the third quartile value and ADTA is less than the median value, then the sample is classified into group 2. If average percentile rank of the number of press releases per six-month period over $\mathrm{M}(-4)$ through $\mathrm{M}(0)$ is less than the first quartile value and ADTA is greater than or equal to the median value, then the sample is classified into group 3. If average percentile rank of the number of press releases per six-month period over M(-4) through $\mathrm{M}(0)$ is less than the first quartile value and ADTA is less than the median value, then the sample is classified into group 4 . ***, **, * significant at the $1 \%, 5 \%$, and $10 \%$ levels, respectively. 
TABLE VI

Regression analyses: Long term, post-issue return performance on disclosure and earnings management

Panel A: Regression with continuous variables

Dependent variables
Monthly abnormal returns from Fama French three-factor
estimated over 12 months
estimated over 24 months
estimated over 36 months
estimated over 48 months
estimated over 60 months
Panel B: Regression with group dummies
Dependent variables

Intercept

odel

-0.0475
$(-5.46) * * *$
-0.0300

$-0.0300$

$(-4.55)^{* * *}$

$-0.0211$

$(-2.96)^{* *}$

$(-3.63)^{* * *}$

$-0.0240$

$(-4.05)^{* * *}$

$\begin{array}{r} \\ \hline\end{array}$

Independent variables

\begin{tabular}{cccc}
\multicolumn{4}{c}{ Independent variables } \\
ADTA & SIZE & BM & LEV \\
& & & \\
-0.0197 & 0.0040 & 0.0106 & 0.0001 \\
$(-2.25)^{* *}$ & $(2.41)^{* *}$ & $(2.21)^{* *}$ & $(0.57)$ \\
-0.0167 & 0.0024 & 0.0022 & 0.0001 \\
$(-2.37)^{* *}$ & $(2.00)^{* *}$ & $(0.58)$ & $(0.64)$ \\
-0.0205 & 0.0031 & -0.0021 & 0.0001 \\
$(-2.79)^{* * *}$ & $(2.30)^{* *}$ & $(-0.53)$ & $(1.25)$ \\
-0.0247 & 0.0044 & -0.0042 & 0.0001 \\
$(-3.58)^{* * *}$ & $(3.45)^{* * *}$ & $(-1.11)$ & $(0.51)$ \\
-0.0214 & 0.0025 & -0.0001 & 0.0001 \\
$(-3.32)^{* * *}$ & $(2.35)^{* *}$ & $(-0.03)$ & $(0.45)$
\end{tabular}

Independent variables

Intercept

Monthly abnormal returns from Fama French three-factor model

estimated over 12 months

estimated over 24 months

estimated over 36 months

estimated over 48 months

estimated over 60 months

-0.0408
$(-5.17)^{* * *}$
-0.0253
$(-4.08)^{* * *}$
-0.0198
$(-2.99)^{* * *}$
-0.0204
$(-3.21)^{* * *}$
-0.0254
$(-4.06)^{* * *}$

\begin{tabular}{cccccccc}
\multicolumn{7}{c}{ Independent variables } & $\begin{array}{c}\text { Adjusted } \\
R^{2}\end{array}$ \\
\cline { 1 - 2 }$\_H E M$ & HDL_LEM & LDL_HEM & LDL_LEM & SIZE & BM & LEV & $R^{2}$ \\
0.0006 & 0.0115 & -0.0073 & -0.0007 & 0.0036 & 0.0106 & 0.0001 & 0.0144 \\
$(0.10)$ & $(2.01)^{* *}$ & $(-1.28)$ & $(-0.10)$ & $(2.10)^{* *}$ & $(2.10)^{* *}$ & $(0.34)$ & \\
0.0034 & 0.0068 & -0.0092 & -0.0003 & 0.0025 & 0.0027 & 0.0001 & 0.0092 \\
$(0.67)$ & $(1.47)$ & $(-1.96)^{* *}$ & $(-0.05)$ & $(1.92)^{*}$ & $(0.64)$ & $(0.35)$ & \\
0.0056 & 0.0017 & -0.0113 & 0.0047 & 0.0030 & -0.0010 & 0.0001 & 0.0121 \\
$(1.06)$ & $(0.35)$ & $(-2.30)^{* *}$ & $(0.84)$ & $(2.06)^{* *}$ & $(-0.23)$ & $(0.81)$ & \\
0.0037 & 0.0030 & -0.0123 & -0.0002 & 0.0042 & -0.0031 & 0.0001 & 0.0204 \\
$(0.73)$ & $(0.65)$ & $(-2.61)^{* * *}$ & $(-0.04)$ & $(3.01)^{* * *}$ & $(-0.75)$ & $(0.12)$ & \\
0.0047 & 0.0032 & -0.0084 & -0.0011 & 0.0030 & 0.0018 & 0.0001 & 0.0211 \\
$(0.96)$ & $(0.70)$ & $(-1.86)^{*}$ & $(-0.21)$ & $(2.76)^{* * *}$ & $(0.46)$ & $(0.11)$ &
\end{tabular}

Adjusted

$R^{2}$

0.0253

0.0180

0.0186

0.0408

0.0298 justed

0121

This table presents the regression of post-issue returns up to five years after $\mathrm{Q}(+2)$ earnings announcement on disclosure and earnings management. Three-factor model $\alpha$ coefficients are alphas from the Fama-French three-factor model estimated over 12 to 60 month periods after the Q $(+2)$ earnings announcement. The following regression is estimated for each firm: $\left(R_{i t}-R_{f t}\right)=\alpha+b_{1}\left(R_{m t}-R_{f t}\right)+b_{2} S M B_{t}+b_{3} H M L_{t}+e_{i t}$ where $\mathrm{R}_{\mathrm{it}}$ is monthly return of SEO firm in 12 to 60 month periods after the $\mathrm{Q}(+2)$ earnings announcement. DL: average percentile rank of the number of press releases per six-month period over $\mathrm{M}(-4)$ through $\mathrm{M}(+3)$; ADTA: annualized performance adjusted discretionary total accruals over the period Q $(-1)$ through Q $(+2)$ scaled by lagged total assets; HDL_HEM: one if DL is greater than the third quartile value and ADTA is greater than or equal to the median value, zero otherwise; SIZE: log of the market value of equity at $\mathrm{Q}(-1)$; BM: book value of equity divided by the market value of equity at Q(-1); LEV: debt-to-equity ratio; HDL HEM: one if DL is greater than the third quartile value and ADTA is less than the median value, zero otherwise; LDL_HEM: one if DL is less than the first quartile value and ADTA is greater than or equal to the median value, zero otherwise; LDL_LEM: one if DL is less than the first quartile value and ADTA is less than the median value, zero otherwise. In Panel B, the intercept captures the returns for firms with two middle quartile (second and third quartiles) values of DLs. ***,**, * significant at the $1 \%, 5 \%$, and $10 \%$ levels, respectively. $t$-values are in the parentheses. 


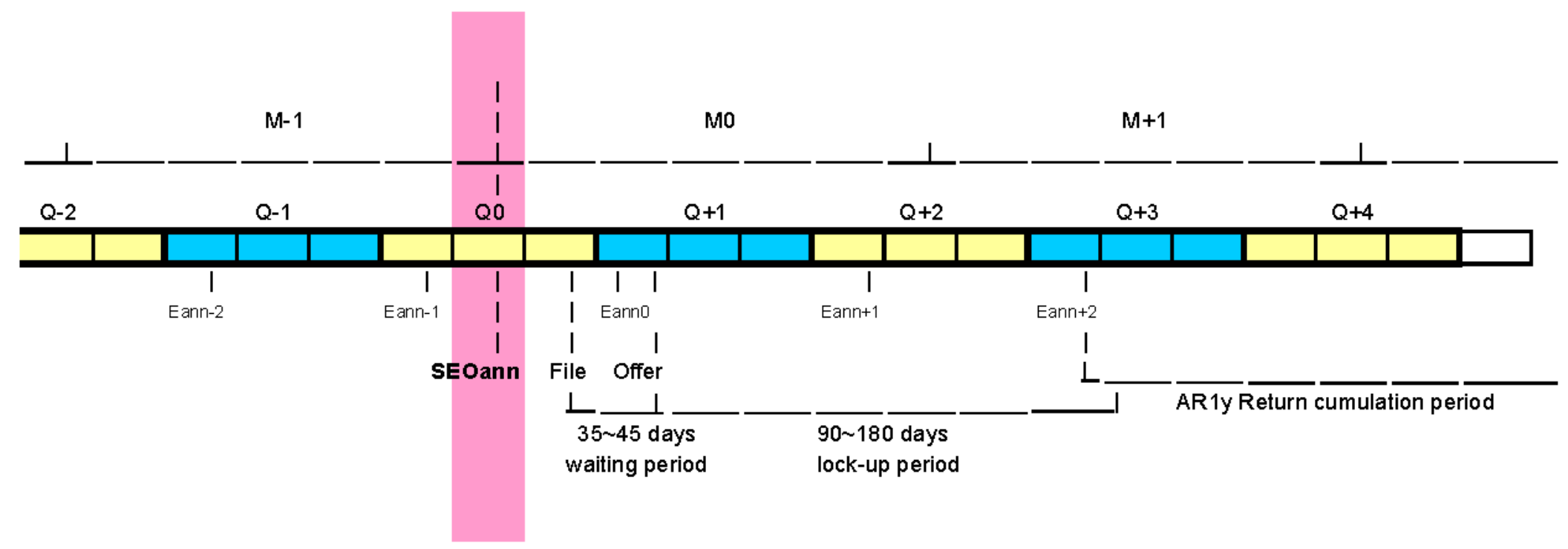

Figure 1. Time line of seasoned equity offerings.

This figure shows our timing convention. Q(.) represents the quarters around a SEO. The quarter of the last earnings announcement before the offering announcement is labeled $\mathrm{Q}(-1)$. $\mathrm{Q}(0)$ is the quarter of the first earnings announcement after the offering announcement. All other quarters are similarly indexed relative to the offering announcement. $\mathrm{M}($.$) is the six-month period in which disclosure frequencies are determined. \mathrm{M}(-1)$ is the last six-month period prior to the SEO announcement, and $\mathrm{M}(0)$ is the first six-month period after the SEO announcement. All other six-month periods are similarly indexed relative to the offering announcement. Eann stands for earnings announcement. We measure post-issue returns by compounding daily market-adjusted returns over the oneyear period after the $\mathrm{Q}(+2)$ earnings announcement. The figure also illustrates important event dates and periods around SEO. 1933 Securities Act prohibits any "offer to sell" prior to the filing of the registration statement before the file of the offer. It also prohibits any sales prior to the effective date. The period between the date of file and the effective date is "Waiting Period". The average Waiting Period in Rangan (1998) is 35 days. In our sample the average Waiting Period is 49 days and the median is 35 days. Lock-up agreements between issuing firms and their underwriters prevent insiders at issuing firms from selling their holdings until 90 to 180 days after the offering date. 


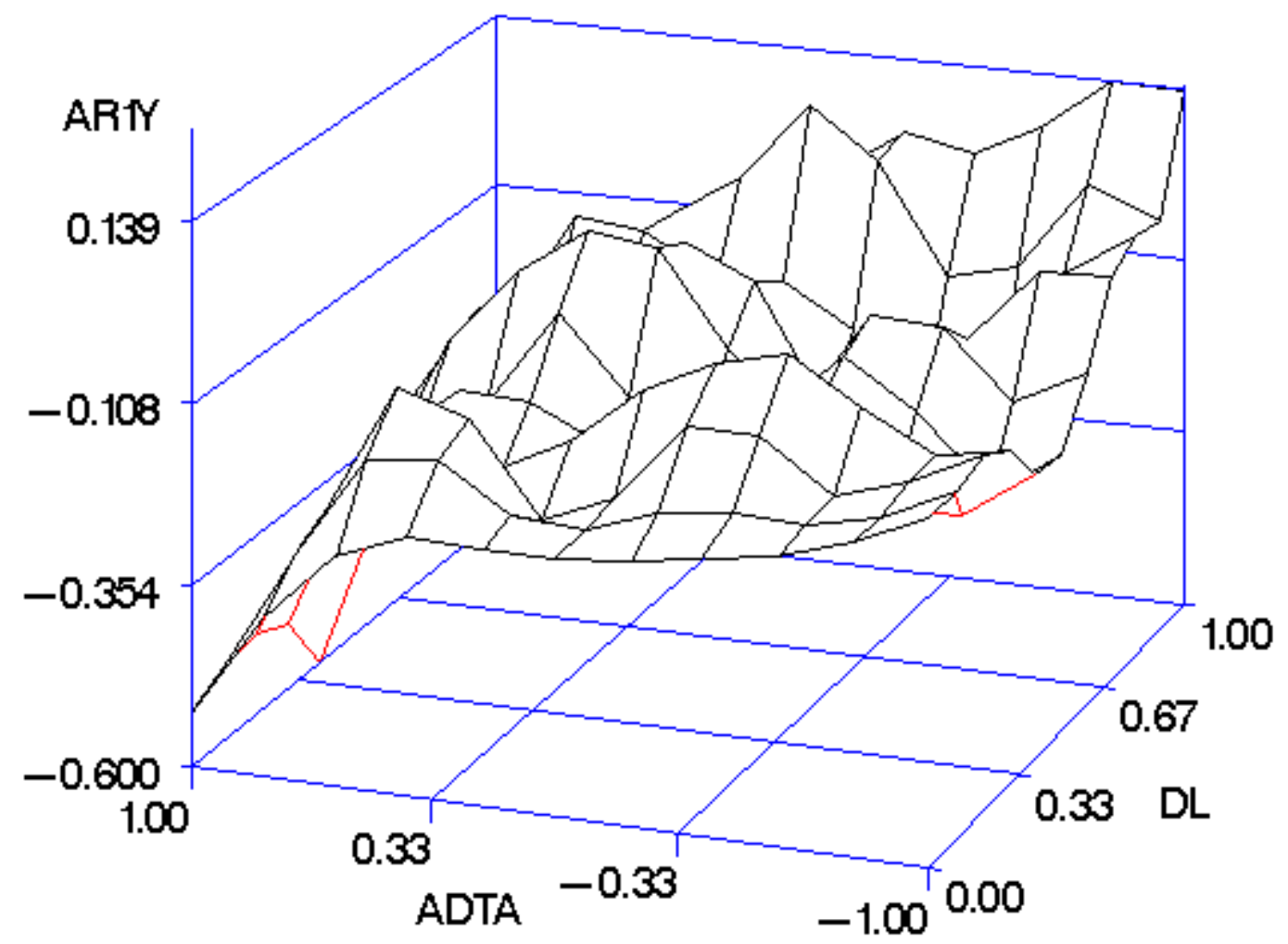

Figure 2. Relationship among disclosure, earnings management, and post-issue returns.

This figure illustrates bivariate relationship among disclosure, earnings management, and the post-issue performance of SEO firms. AR1Y is market adjusted returns compounded daily over the one-year period after the Q(+2) earnings announcement. DL, our measure of disclosure frequency, is average percentile rank of the number of press releases per six-month period over $\mathrm{M}(-4)$ through $\mathrm{M}(+3)$. ADTA, our measure of earnings management, are annualized performance-adjusted discretionary total accruals over the period $\mathrm{Q}(-1)$ through $\mathrm{Q}(+2)$ scaled by lagged assets. For a better presentation, ADTA is converted to the standardized percentile rank. We first rank ADTA and convert it to percentiles by taking (rank-1)/(number of samples-1). We then standardize the percentile by taking (percentile rank $0.5) / 0.5$, so that the final measure falls in the range between -1 and 1 . 